\title{
FASCIOLIASIS IN DAIRY CATTLE IN THE RIO PLATA BASIN OF THE DORADO AREA, PUERTO RICO', :
}

Fasciola hepatica is the most widespread species of liverfluke of cattle, sheep and goats. This parasitc was officially recorded as occurring in Puerto Rico by van Volkenberg in $1939,{ }^{3}$ but observations and collections of it may have been made as early as 1924 .

An accurate estimate of loss to the livestock industry in Puerto Rico due to fascioliasis is not easy to make. However, direct loss due to condemnation of infested livers at time of slaughter are available. Recent examination of Department of Health records reveal that fluke-infested livers were condemned from 12 percent of the cattle killed at the slaughterhouses in the entire Island from January to June 1969. This represents a direct loss to the livestock industry of at least $\$ 600,000$. The value of other direct losses, such as deaths from fascioliasis, cost of treatment, etc., are difficult to estimate. Losses due to indirect causes such as reduction of milk production, poor feed conversion, low meat quality and others are even more difficult to evaluate.

The extent of liverfluke infestation of cattle in Puerto Rico, based on a slaughterhouse survey, has been reported by Rivera-Anaya and Martínezde Jesús. ${ }^{4}$ These authors tabulated percentages of infected animals by municipalities, by districts, and for the entire Island. However, they did not indicate the origin of the farm where the infected animals came from. Such information is necessary for the determination of most heavily infected areas, degree of infection, or the snail intermediate hosts, all essential for instituting adequate and proper control measures against the parasite. 5

The present investigation was designed for the purpose of establishing some of this essential information.

A total of 19 class A dairy farms on the Río Plata basin of the Dorado, Toa Baja, and Toa Alta municipalitics were selected for this study con-

${ }^{2}$ Manuscript submitted to Editorial Board 9 July 1971.

2 This note presents partial results of a cooperative project between the Department of Agriculture of Puerto Rico, the Agricultural Experiment Station, and the Puerto Rico Nuclear Center, University of Puerto Rico, on the control of Fasciola hepatica in Puerto Rico. Thanks are expressed to Mr. Félix Liard, Jr. and Miss Mercedes Vargas, Puerto Rico Nuclear Center, for the photograph and the dissection of the snails, respectively.

${ }^{3}$ Van Volkenberg, H. L., An annotated checklist of the parasites of animals in Puerto Rico, P. R. Exp. Sta. Circ. 22, 1939.

${ }^{4}$ Rivera-Anaya, J. D. and Martinez-de Jesús, J., The extent of liver-fluke infestation of eattle in Puerto Rico (A slaughterhouse survey), Agr. Exp. Sta. Univ. P. R., Bull. 107, 1952.

${ }^{6}$ Bell, R. R., A study of Fasciola hepatica, report to the Secretory of P. R. Department of Agriculture, 1968. 
ducted from January 1970 to March 1971. Eleven of the farms are situated in Dorado, 5 in Toa Baja, and 3 in Toa Alta. There were 5,315 cows on these farms, of which 1,229 were examined, representing an overall 20percent sample.

Stool specimens were collected after morning milking. Defecation usually follows when cows are released from milking stanchions. The fecal samples were collected from the floor, kept in paper cups, properly identified per cow, and brought to the laboratory for diagnostic examination.

Two g. of feces were concentrated by means of the ether-sedimentation technique using a buffered alcoholic medium ${ }^{6}$ with adaptations for cow feces. Microscopic slide preparations were made with a methyl green solution that stained the debris but left the eggs unstained. This staining procedure was recommended to us by Ueno ${ }^{7}$ to help distinguish the eggs of $F$. hepatica from those of a commonly occurring paramphistomid. The respective distinguishing features used for differential identification of liverfluke eggs from paramphistomid eggs were amber vs. silver color, fine vs. course yolk granules, anterior vs. middle location of embryo in the egg, less conspicuous vs. more conspicuous lid, and elliptical shape vs. a tendency towards an urn shape. All eggs were counted on a systematic basis.

A search was made for snail intermediate-host species on all the farms during February and March 1970 and February and March 1971. The collected snails were identified as to species, subsequently dissected, and examined under a stereoscopic microscope for the different stages of Fasciola. Immature and mature infections of Fasciola and the paramphistomid parasite were carefully distinguished.

Table 1 shows the prevalence of $F$. hepatica in 1970 among dairy cows studied. In Dorado, nine of the 11 farms have fascioliasis with 11 to 56 percent of the animals positive for the infection. All five farms in Toa Baja were positive for liverfluke, with infection rates of 18 to 80 percent. The three farms in Toa Alta also were positive, with infection rates of 5 to 79 perent. The overall infection rate for the 1,229 cows was 37 percent.

Actual prevalence of Fasciola-infection probably is higher in the study area than shown in table 1; sedimentation techniques for diagnosis although reliable are not perfect. Happich and Boray ${ }^{8}$ have shown that only one-

' Ritchie, L. S., Lin, S., Moon, A. P., Frick, L. P., Williams, J. E., Asakura, S., and Hishnuma, $\mathrm{Y}$., The possible effects of $\mathrm{pH}$ and specific gravity on the ether-sedimentation procedure in concentrating eggs and cysts, Am. J. Trop. Med. and Hyg. 4: $444-9,1960$.

7 Ueno, H., private communication, 1970.

${ }^{8}$ Happich, F. A. and Boray, J. C., Quantitative Diagnosis of Chronic Fascioliasis, 1 Comparative Studies on Quantitative Faecal Examinations for Chronic Fasciola hepatica Infection in Sheep, The Austral. Vet. J., 45 (7): 326-28, 1969. 
Table 1.-The prevalence of Fasciola hepatica (L. 1758) among dairy cows in the Dorado Area, 1970

\begin{tabular}{|c|c|c|c|}
\hline Farm number and location & Cows in herd & $\begin{array}{l}\text { Cows } \\
\text { examined }\end{array}$ & $\begin{array}{l}\text { F. hepalica } \\
\text { infection }\end{array}$ \\
\hline & Number & Number & Percent \\
\hline 1. Barrio Mameyal, Dorado & 413 & 70 & 51 \\
\hline 2. Barrio Higuillar, Dorado & 134 & 47 & 51 \\
\hline 3. Barrio Higuillar, Dorado & 180 & 50 & 26 \\
\hline 4. Barrio Higuillar, Dorado & 483 & 70 & 11 \\
\hline 5. Barrio Higuillar, Dorado & 300 & 59 & 56 \\
\hline 6. Barrio Higuillar, Dorado & 125 & 50 & 52 \\
\hline 7. Barrio Maguayo, Dorado & 420 & 68 & 34 \\
\hline 8. Barrio Río Nuevo, Dorado & 324 & 54 & 33 \\
\hline 9. Barrio Espinosa, Dorado & 60 & 30 & 0 \\
\hline 10. Barrio Río Lajas, Dorado & 260 & 66 & 38 \\
\hline 11. Barrio Los Puertos, Dorado & 531 & 74 & 0 \\
\hline 12. Barrio Media Luna, Toa Baja & 125 & 75 & 35 \\
\hline 13. Barrio Media Luna, 'Toa Baja & 560 & 75 & 36 \\
\hline 14. Barrio Media Luna, Toa Baja & 125 & 50 & 18 \\
\hline 15. Barrio Campanilla, Toa Baja & 250 & 50 & 28 \\
\hline 16. Barrio San José, Toa Baja & 550 & 75 & 80 \\
\hline 17. Barrio Bucarabones, Toa Alta & 195 & 129 & 79 \\
\hline 18. Barrio Vega Grande, Ton Alta & 180 & 98 & 25 \\
\hline 19. Barrio Ortiz, Toa Alta & 100 & 35 & 5 \\
\hline Total & 5,315 & 1,229 & $37^{1}$ \\
\hline
\end{tabular}

1:Percent (average) infestation of total cows under surveillance.

third of liverfluke eggs are recoverable from cattle containing 100 eggs per g. of feces by the sedimentation technique. Further, Dorsman, as cited by Pantelouris, ${ }^{9}$ demonstrated that diurnal fluctuation oceurs in the number of eggs in the feces of eattle infected with $F$. hepatica; that the egg count increases progressively during the morning to a peak near mid-day and declines thereafter to a low during the night. Correspondingly, the number of eggs in the stools examined during this investigation may have been relatively low because all stools were collected carly in the morning.

It is interesting that concurrent with fascioliasis, 18 of the 19 farms also have paramphistomid infection ranging from 4 to 95 pereent. The adult form of paramphistomids 10 are located in the rumen (forestomach) and are said to be essentially non-pathogenic although large numbers may be present.

Four species of fresh-water snails, Lymnaea cubensis, Lymnaea columella,

- Pantelouris, E. M., The Common Liverfluke, Fasciola hepatica L., Pergamon Press, New York, N.Y. 259 pp., 1965.

${ }^{10}$ Soulsby, E. J. L., Helminths, Arthropods and Protozoa of Domesticated Animals, Williams and Wilkins, Baltimore, Md. 824 pp., 1968. 


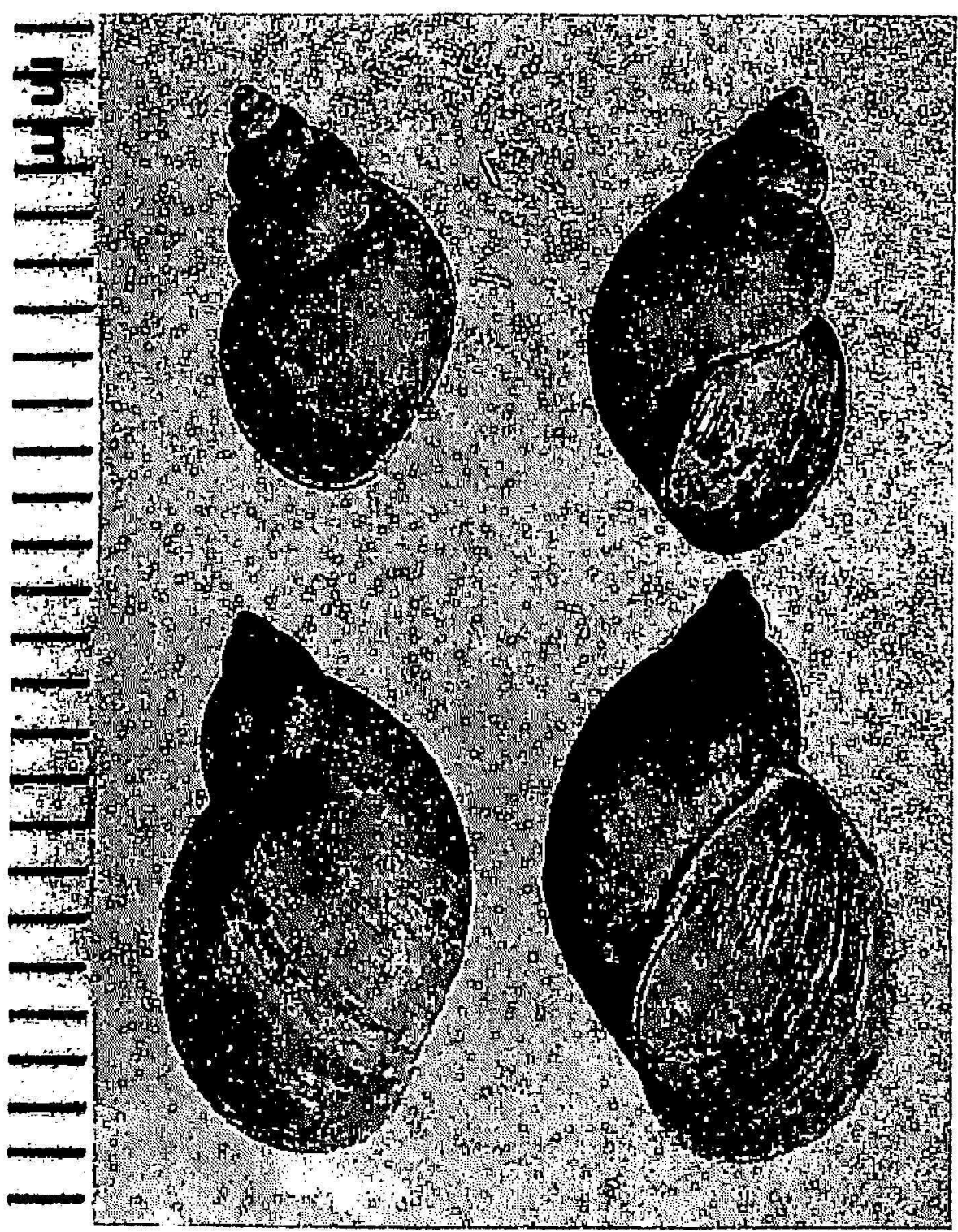

Fig. 1-Lymnaea cubensis (above), Lymnaca columella (below).

Physa cubensis, and A plexa marmorala were collected on the farms surveyed. $P$. cubensis and A. marmorata were counted and discarded because they are not intermediate hosts of $F$. hepatica in Puerto Rico. ${ }^{11}$

The intermediate snail hosts, $L$. cubensis and $L$. columella, are shown in fig. 1. The rates of infection of $F$. hepatica in the snail vectors during February and March 1971 in the Dorado-Toa Baja-Toa Alta municipalities are shown in table 2. The data collected during February and March 1970 are not included in this report because small numbers of snails were collected and most of these were negative for liverfluke. Either one or both lymnaeid species were found on 14 of the 19 farms. Only L. cubensis was found on 11 farms, only L. columella on one farm, both species on two farms. Infected

"1 De León, D., Ritchie, J.. S., and Chiriboga, J., Refractiveness of Physa cubensis (l'feiffer) and A plexa marmorata (Guilding) to Fasciola hepatica (Lin.), J. Agr. Univ. P. R. 55 (2) : 267-70, 1971. 
TABLE 2.-The snail intermediate hosts and rate of infection of Fasciola hepatica (L. 1758), February-March, 1971, Dorado Area

\begin{tabular}{llrc}
\hline \multicolumn{1}{c}{ Farm number and location } & Snail intermediate hosts & $\begin{array}{c}\text { Snails } \\
\text { examined }\end{array}$ & $\begin{array}{c}\text { Snails } \\
\text { infected } \\
\text { with } F \\
\text { hepafica }\end{array}$ \\
\hline 1. Barrio Mameyal, Dorado & Lymnaea cubensis & Number & Percent \\
2. Barrio Higuillar, Dorado & L. cubensis & 200 & 4 \\
& Lymnaea columella & 175 & 5 \\
3. Barrio Higuillar, Dorado & L. cubensis & 25 & 0 \\
4. Barrio Higuillar, Dorado & L. columella & 100 & 4 \\
5. Barrio Higuillar, Dorado & L. columella & 12 & 0 \\
6. Barrio Higuillar, Dorado & L. cubensis & 200 & 0 \\
7. Barrio Maguayo, Dorado & L. cubensis & 182 & 26 \\
8. Barrio Río Nuevo, Dorado & L. cubensis & 200 & 6 \\
9. Barrio Espinosa, Dorado & L. cubensis & 157 & 4 \\
10. Barrio Río Lajas, Dorado & 0 & 0 & 0 \\
11. Barrio Los Puertos, Dorado & L. cubensis & 140 & 4 \\
12. Barrio Media Luna, Toa Baja & L. cubensis & 70 & 0 \\
13. Barrio Media Luna, Toa Baja & 0 & 0 & 0 \\
14. Barrio Media Luna, Toa Baja & L. cubensis & 0 & 0 \\
15. Barrio Campanilla, Toa Baja & L. cubensis & 182 & 0.5 \\
16. Barrio San José, Toa Baja & L. cubensis & 120 & 4 \\
17. Barrio Bucarabones, Toa Alta & L. cubensis & 239 & 17 \\
18. Barrio Vega Grande, Toa Alta & 100 & 27 \\
19. Barrio Ortiz, Toa Alta & 0 & 0 & 0 \\
\hline & 0 & 0 & 0 \\
\hline
\end{tabular}

snails occurred in the collections of 11 of 14 farms where snails were found. The highest rate of infection was 27 percent, while this figure was 6 pereent or less on eight farms.

On the basis of occurrence alone, $L$. cubensis can be considered the primary intermediate host of $F$. hepatica in the Dorado Area; positive specimens were not encountered in the collections of $L$. columella. However, the latter species occurs naturally infected in other parts of the Island and is readily susceptible to experimental exposure..$^{12}$

It is surmised that heavy rainfalls and floods during the late months of 1970 helped increase population densities of the snails; areas negative for snails in 1970 were densely populated in February and March 1971.

Delfin de León

Department of Animal Husbandry L. S. Ritchie and J. Chiriboga

Puerto Rico Nuclear Center

University of Puerto Rico

12 De León, D. D., Life history of Lymnaea columnella (Say) and its experimental infection with Fasciola hepatica (Lin.), J. Agr. Univ. P. R. 54 (2) : 297-305, 1970. 